at vende tilbage til hende og barnet med jagtbytte. Samtidig indeholder kontrakten et løfte til parterne om deres fremtidige adfærd. Påstanden er, at et sådant rituelt løfte blot kræver en rudimentær symbolsk evne. Man har benyttet sig af et eller andet - nu til dags er det en ring på højre ringfinger - til at vise hinanden og stammens øvrige medlemmer, at man har indgået et forpligtende samarbejde (i medgang og modgang).

Der er altså opstået et pres på de tidlige mennesker for at kunne benytte sig af symboler, og hjernen og brugen af symboler har nu kunnet udvikle sig sammen. Forudsætningen for den videre hjerneudvikling er evnen til at kunne jonglere med symboler - sproget har besat hjernen - og ikke omvendt, skriver Hoffmeyer (338ff). Dette scenarium gør det nemt at se, hvorledes etno-kulturelle specialiteter kan besætte hjernen sammen med sproget. Kulturen ligger ikke i generne, men i tegnene, og disse stiver kulturen og det enkelte individs identitetsfølelse af i så høj grad, at vi bilder os ind, at vi aldrig ville kunne leve med andres vaner.

Om tesen - eller teserne - holder stik eller om det biosemiotiske begrebsapparat vil udbrede sig, vil kun fremtidens forskning og teoretiske diskussioner vise. Hoffmeyer har med sine diskussioner af biologiens historie og teoretiske grundlag, med de mangfoldige eksempler og modige spekulationer lagt grunden for en ny måde at favne naturens mangfoldig- hed på - og har heri fundet plads til menneskets forunderlige kommunikative og sproglige evner.

Der er meget $\mathrm{i}$ afhandlingen, der burde kunne interessere humanister, ikke mindst Hoffmeyers diskussion af termodynamikken, den velbegrundede idé om naturlove som vaner og hans opgør med den klassiske mekaniks enstrengede kausalitetsforståelse.

Vi har med afhandlingen, Biosemiotike, fået en usædvanlig Doktor Phil. nemlig en naturvidenskabsmand, en molekylærbiolog med en grad ud i filosofien. Tilbage er blot at ønske Jesper Hoffmeyer tillykke med titlen.

Lars Andreassen

\section{Paven og demokratiets frelsende engel}

Jürgen Habermas og Joseph Ratzinger: Dialektik der Säkularisierung. Über Vernunft und Religion, Herder, 2005, 64 sider, € 9,90. På dansk: Fornuft og religion. Sekulariseringens dialektik, Hovedland, 2006, 77 sider, kr. 138,-

Hvilken rolle kan religion tildeles i moderne, sekulære demokratier? Giver religiøse fortolkninger af livet blot anledning til antidemokratisk fundamentalisme eller rummer religion et potentiale, der kan styrke samfundets fortsatte demokratisering? Det forsøger den tyske filosof Jürgen Habermas (f. 1929) og den ligeledes tyske teolog Joseph Ratzinger (f. 1927), nu 
pave Benedikt XVI, at svare på $\mathrm{i}$ to essays, som tilsammen udgør bogen Dialektik der Säkularisierung. Über Vernunft und Religion.

Selv om kvaliteten er lidt svingende, er der store indsigter at hente $\mathrm{i}$ bogen, ikke mindst hos Habermas, der som altid er god for en lektion i, hvad demokrati egentlig er. Han er en offentligt engageret intellektuel med en fantstiske evne til at pege på, hvordan demokratiet overvinder kriser - globaliseringen, fundamentalismen, terrorismen - og kommer videre på demokratiets egne præmisser. Det er prisværdigt og et vigtigt stykke arbejde $\mathrm{i}$ en tid, hvor herskende nationalistiske, nykonservative og nyliberalistiske strømninger søger det fælles - det der skal sikre samfundets sammenhængskraft - inden for rammerne af præpolitiske værdier som nationalitet, etnicitet og forbrugerfællesskab. For en demokratisk betragtning er sådanne bestemmelser af det almene en tvivlsom fornyelse.

Habermas' tese er, at netop fordi ingen kultur eller religion i multikulturalismens tidsalder kan tildeles forrang, må samfundet, nationalt såvel som internationalt, bindes sammen af de demokratiske, politiske principper: anerkendelsen af individers og kulturers ligeværd, tolerance og respekt for den anden.

Ganske vist fordrer demokrati, at religion gøres til en privatsag, men det betyder ikke, at religiøse argumenter på forhånd er frataget berettigelse $i$ den offentlige debat. Habermas in- sisterer på, at vi ikke på forhånd må fraskrive religiøse verdensanskuelser et sandhedspotentiale, eftersom de er arnested for en omsorg for tilværelsens etiske og kollektive dimensioner, som synes at være gået tabt i den teknokapitalistiske modernitets snævre fokusering på nyttemaksimering. Men det gælder for religiøse argumenter som for alle andre: De skal retfærdiggøres rationelt og efterprøves kritisk, før end de kan gøre krav på gyldighed i et sekulært demokratisk samfund. Begrebet tolerance er et nærliggende eksempel på denne proces. Det er et begreb, som har rødder i den kristne forestilling om næstekærlighed, men som netop har udkrystalliseret sig i sin sekulære form ved at have frigjort sig fra den dogmatiske lære, næstekærligheden er indspundet $i$, og som nu udgør en hjørnesten i ethvert sekulært demokratis selvforståelse.

Ratzinger træder mere varsomt end Habermas. Hans essay er ikke dårligt, men heller ikke den store åbenbaring. Habermas' essay synes i langt højere grad at være ude i et ærinde - nemlig at præcisere, hvordan vi må forstå forholdet fornuft-religion - end tilfældet er hos Ratzinger. Ratzinger diagnosticerer en række udfordringer - terrorismen, globaliseringen, naturvidenskabens altdominerende stilling - og han synes specielt bekymret for fremtidens muligheder for gennem kloning at frembringe mennesker på kunstig vis. Mens Habermas' forgængere på Socialforskningsinstituttet i Frankfurt påviste, hvordan menneskets forhold 
til sig selv og sine medmennesker er blevet tingsliggjort, fremfører Ratzinger, at mennesket i sig selv er ved at udvikle sig til en ting. Genteknologien er blot ét eksempel på, at fornuften er gået amok. Derfor har den brug for en instans, der kan begrænse og korrigere den, og denne instans er ifølge Ratzinger religionen.

Habermas og Ratzinger er således enige om, at fornuft og religion gensidigt kan korrigere hinanden og bør indgå i et dialogisk forhold. Og de er også enige om, at etableringen af en kosmopolitisk ret, som allerede Kant efterspurgte, er et must, hvis den multikulturelle verden skal kunne hænge sammen. Men derudover stiller Ratzinger et spørgsmål, som ikke har nogen plads inden for Habermas' diskursetik, der som bekendt fokuserer på, hvordan normer kan legitimeres rationelt og ikke hvilke normer, der bør legitimeres, nemlig spørgsmålet om forholdet mellem positiv ret og naturret. Den menneskelige væren er i sig selv bærer af værdier og normer, som det ikke står til os at opfinde, men som det er os pålagt at leve op til, og som må fastholdes på tværs af de positive retssystemer - islamiske, kristne, hinduistiske og demokratiske - hvis vi skal gøre os forhåbninger om fredelig sameksistens.

Så alt $i$ alt er der tale om en anbefalelsesværdig bog, der synes at blive stadig mere aktuel i takt med at konfrontationen mellem religiøse og sekulære samfund spidser til.

Rasmus Navntoft

\section{Kom nu!}

Samtaler med tidsainden og oprab imod den - Fra Ejvind Larsens 50 år på Information, redaktion ved Rune Lykkeberg, Informations Forlag 2005, 231 sider, kr. 248 ,-

Bogen Samtaler med tidsainden og opräb imod den er først og fremmest en velkomponeret hyldest til mennesket Ejvind 'Mangeord' Larsen, der igennem en menneskealder har virket som ildsjæl og åndelig indpisker ved Dagbladet Information. Som opmærksom politisk analytiker, som kritisk åndsarbejder, og som visionær folkelig vækkelsesprædikant. Til mennesket Larsen, der storrygende og jamrende sig over tidens elendighed - 'Verden er af lave!'-, alligevel ikke kan lade være med at stå op bare en gang til og råbe op med og mest imod tidsånden. Hvileløs i sin jagt på tidens falske ideologier og vanetænkning, og i sin gentagne opfordring til den danske folkelighed om at vågne op og gøre sig fri af dens egen selvforskyldte umyndighed: Kom nu!

Men bogen er meget mere end det. Den er også et lille stykke Danmarkshistorie, efterkrigstidens Danmark set inde fra en avis, Dagbladet Information. Et blik på den store historie set fra den flere gange lukningstruede avis' intime redaktionslokaler og fra Larsens hule på Esplanaden i København. Men den er også et stykke kulturhistorie, idet man her stifter bekendtskab med forfatterpersonligheder som Bjørn Poulsen og Villy 